\title{
Roundness of survivor clasts as a discriminator for melting and crushing origin of fault rocks: A reappraisal
}

\author{
Arindam Sarkar, Anupam Chattopadhyay* and Tusharika Singh \\ Department of Geology, University of Delhi, Delhi 11000\%, India. \\ *Corresponding author.e-mail: anupamchatto@gmail.com
}

MS received 31 October 2017; revised 23 April 2018; accepted 12 May 2018; published online 25 February 2019

Roundness of survivor clasts (mineral/rock fragments) in fault rocks (e.g., pseudotachylyte and cataclasite/gouge) has been used by some workers to distinguish melt-origin from crush-origin of such rocks. Keeping in view the large overlap in the published data on the roundness of fault rocks, the reliability of such a discriminator appears somewhat uncertain. The present study attempts to reappraise the aforesaid criterion through roundness analysis of quartz and feldspar clasts in melting-dominated pseudotachylyte (M-Pt), crushing-dominated pseudotachylyte (C-Pt) and fault-related cataclasite (F-Ct) collected from Sarwar-Junia Fault Zone in Rajasthan and from Gavilgarh-Tan Shear Zone in central India. Our analysis shows that roundness of clasts cannot reliably distinguish between fault rocks of melt-origin and crush-origin (especially $\mathrm{M}-\mathrm{Pt}$ and $\mathrm{F}-\mathrm{Ct}$ ) as the roundness values overlap and a distinct limit of roundness value for each rock type cannot be established. While the roundness of clasts in M-Pt and C-Pt may be enhanced due to melt-induced rounding off of the initially angular clasts, rounding of clasts can also occur by abrasion during rolling of crushed material in F-Ct. Furthermore, anomalous thermal expansion of clasts in melt-origin pseudotachylyte may cause disintegration of larger clasts into smaller angular fragments, thereby increasing the percentage of angular clasts in melt-origin fault rocks. Therefore, roundness of survivor clasts cannot be solely used as a discriminator between melt-origin and crush-origin fault rocks.

Keywords. Pseudotachylyte; cataclasite; survivor clasts; roundness; melting.

\section{Introduction}

Pseudotachylyte (Pt) is a dark-coloured, glassy aphanitic rock either associated with meteorite impact events (Shand 1916; Reimold and Gibson 2005), or with large landslides (Legros et al. 2000), but most commonly with seismogenic faults in the upper crust (Sibson 1975; Magloughlin and Spray 1992; Di Toro and Pennacchioni 2004). Faultrelated pseudotachylyte is believed to be a product of localised crushing and melting of the host rock during rapid ( $\geq 1.0 \mathrm{~m} / \mathrm{s}$ ) fault slip (McKenzie and Brune 1972; Sibson 1975; Cowan 1999). In the outcrop scale, pseudotachylyte usually occurs as a network of veins, filling the fractures associated with a fault zone. Texturally, pseudotachylyte is composed of numerous fragments (clasts) of the host rock randomly distributed in an ultra-fine grained glassy matrix (Sibson 1977; Lin 2008). Most often, the glass originally present in the matrix of pseudotachylyte veins devitrifies to secondary phases and identification of the glass phase becomes difficult (Wenk 1978; Kirkpatrick et al. 2012). The lack of an identifiable glass phase in pseudotachylyte initially led to a major controversy regarding the melt origin of these rocks, and 
some workers argued that they are a product of ultracataclasis only (Wenk 1978; Wenk and Weiss 1982). Identification of typical melt-origin microstructures, e.g., vesicles, amygdules, the presence of fine recrystallised grains (microlites) and spherulitic growth of microlites over relict fragments, etc. have, however, provided much support in favour of the melt origin of pseudotachylytes (Maddock 1983; Lin 1994). At present, majority of the workers believe that pseudotachylytes are produced by a combination of crushing and melting processes, which is also supported by high-speed friction experiments (e.g., Magloughlin 1992; Spray 1995; Lin and Shimamoto 1998). Cowan (1999) has argued that pseudotachylyte is the best marker to identify palaeoseismic activity along a fault plane.

Many workers have attempted to address the issue of melt-origin vs. crush-origin of pseudotachylytes through textural studies. One approach has been grain-size analysis of mineral/rock clasts (i.e., fragments) in natural and experimental pseudotachylytes through microscopy (Shimamoto and Nagahama 1992; Lin 1996; Tsutsumi 1999; Ray 1999, 2004). It has long been identified that crushing of rocks generally produces a Power-law relationship between grain size and frequency (Sammis et al. 1987). Grain size analysis of pseudotachylytes showed that the relation between clast size (clast radius or area) vs. number of clasts (frequency or cumulative frequency) shows a Power-law distribution, except for the finer size fraction where the distribution deviates from the Power law (Shimamoto and Nagahama 1992; Ray 1999; Tsutsumi 1999). This was explained by selective melting of finer clasts and anomalous reduction in their number, thereby supporting the melt-origin. Lin (1999), on the other hand, used roundness of the surviving clasts as a test for the melting vs. crushing origin of pseudotachylytes. Roundness of sedimentary clasts was earlier defined by Wadell (1932) as $R_{\mathrm{d}}=(1 / n) \Sigma\left(r_{i} / R\right)$, where $r_{i}$ is the radius of curvature of the $i$ th corner, $R$ is the radius of curvature of the maximum inscribed circle in the clast in plane and $n$ is the number of corners. Following Wadell's method, Lin (1999) measured roundness of survivor quartz and feldspar clasts ( $>10 \mu$ m diameter) observed in optical and electron microscopy images of melting-origin pseudotachylyte, crushing-origin pseudotachylyte and fault gouge/cataclasite samples. He concluded that clasts with a roundness $\left(R_{\mathrm{d}}\right)$ greater than 0.4 are produced by meltinduced decrepitation along the boundary of the initial mineral fragments, and therefore support melt-origin of the associated pseudotachylyte. The crushing-origin pseudotachylyte and cataclasites show quartz/feldspar clasts mostly with $R_{\mathrm{d}}<0.4$.

In the Indian context, there is relatively less amount of documented work on textural analysis of pseudotachylytes, although there exists a huge volume of work on Indian faults/shear zones. Ray (1999, 2004) first carried out a systematic clast size analysis of melting-dominated pseudotachylytes (M-Pts) from the Sarwar-Junia Fault Zone (SJFZ) in Rajasthan, and demonstrated that the clast size shows a Power-law (fractal) relationship with cumulative frequency, except at the finest clast size range, where it 'falls off' from the ideal Power-law curve, indicating anomalously low count of fine clasts. Using numerical modelling, Ray (2004) showed that uniform melting along the rims of relict clasts in a pseudotachylyte would always generate a fractal size-frequency distribution which falls off at the finer size range due to the near-complete removal of finer clasts from the measured clast population by melting. Recently, Behera et al. (2017) have measured clast size and frequency of relict lithic clasts in pseudotachylyte veins within charnockites of the Southern Granulite Terrain and have reported a fractal relationship similar to that described by the earlier workers. They have also carried out roundness analysis of clasts in the pseudotachylyte and concluded that majority of the clasts have $R_{\mathrm{d}} \geq 0.4$ and support the melt-origin of the studied pseudotachylyte.

Although the roundness analysis of Lin (1999) suggested that the $R_{\mathrm{d}}$ value can distinguish between melt-origin and crush-origin pseudotachylytes/ cataclasites, there is actually a big overlap in the measured $R_{\mathrm{d}}$ ranges of pseudotachylytes and cataclasites presented in his work. Many of the well-known melting-dominated Pt samples (from Outer Hebrides, Musgrave Range and Osumi Fault Zones) showed dominance of clasts with $R_{\mathrm{d}}<0.4$ (figure 4 of Lin 1999). This creates some uncertainty regarding the reliability of roundness $\left(R_{\mathrm{d}}\right)$ value as a distinguishing criterion for melt-origin Pt. In view of this, we have taken up a study of clast roundness of melting-dominated pseudotachylyte (M-Pt), crushing-dominated pseudotachylyte (C-Pt) and fault-related cataclasite (F-Ct) samples collected from different fault/shear zones of India to reappraise the use of roundness as a reliable discriminator between melt-origin and crush-origin fault rocks. 


\section{Description of the fault-rock samples}

To test the effect of melting/crushing on the roundness of clasts in fault rocks, three different types of pseudotachylyte/cataclasite were used in the present study: (i) M-Pt which shows significant melt-origin microstructures indicating frictional melting as a dominant process for its generation; (ii) $\mathrm{C}-\mathrm{Pt}$ which shows dominance of crushing/cataclasis in hand specimen, and under optical microscope, but the presence of a very small amount of melt can be identified under a scanning electron microscope (SEM); (iii) F-Ct which is generated as a result of crushing along the fault zone, and lacks any evidence of melting. M-Pt samples were collected from the SJFZ, Rajasthan, whereas the C-Pt and F-Ct were collected from the Gavilgarh-Tan Shear Zone (GTSZ) in central India.

\subsection{Geological background of the samples}

The $25 \mathrm{~km}$ long, EW trending SJFZ runs through biotite gneisses and sillimanite-garnet schists, belonging to the banded gneissic complex (also called Mangalwar complex in the Ajmer-Bhilwara region by Gupta et al. 1980), generally believed to be the metamorphic basement complex in the Aravalli-Delhi Orogenic Belt (ADOB) of Rajasthan (Heron 1953; Gupta et al. 1980). SJFZ has NNE-SSW striking sub-vertical gneissic foliation, dissected by multiple episodes of brittle crushing within the aforesaid fault zone. From isolated outcrops on two fault strands, the shear/slip sense along the fault appears to be dextral (figure 1a). Brittle shearing has produced pseudotachylyte (M$\mathrm{Pt}$ ) along the fault zone, found in isolated outcrops along its length (figure 1a). Most of the of pseudotachylyte fault-veins (i.e., the melt-generating slip zones parallel to the fault) cross-cut the host rock foliation (figure 2a) whereas many injection veins, emanating from the melt generation zones, have intruded parallel to the foliation planes.

GTSZ (figure 1b) is an ENE-WSW trending brittle-ductile fault zone within the unclassified basement gneisses of the Central Indian Tectonic Zone - a Proterozoic crustal scale mobile belt within the central Indian craton (Chattopadhyay and Khasdeo 2011). Recent work (e.g., Chattopadhyay et al. 2008) has documented that ductile shearing of granitoids in the fault/shear zone generated a series of mylonitic rocks with sinistral shear sense at $T>450^{\circ} \mathrm{C}$ (i.e., at more than $15 \mathrm{~km}$ depth). At a relatively shallower depth (10-15 km), these rocks were overprinted by later generation dextral sense shearing at ductile-brittle transition stage $\left(T \approx 300-400^{\circ} \mathrm{C}\right)$. Subsequently, these rocks were subjected to fully brittle crushing, producing cataclasis-dominated pseudotachylyte (C-Pt) and typical cataclastic rocks (F-Ct) (Chattopadhyay et al. 2008). Dark coloured C-Pt vein systems comprise fault veins parallel to the host rock foliation and a number of injection veins cross-cutting the foliation planes, producing a typical criss-cross brittle fracture network with local crushing of the host rock (figure 2b). Samples of F-Ct were collected from a late brittle fault in the eastern part of GTSZ (Bamniya Nala Fault; figure 1b) which exposes a 5-m wide crush zone comprising brecciated granitic rock cemented by secondary silica. Within this brecciated zone, dark coloured layers of intensely crushed and well cemented cataclasite occur, samples of which were collected for our analysis (figure 2c). No vein of dark material intruding the host rock was observed in association with F-Ct.

\subsection{Microstructural characters of $\mathrm{M}-\mathrm{Pt}, \mathrm{C}-\mathrm{Pt}$ and F-Ct}

M-Pt veins reveal several pieces of evidence of melting under optical microscope. In the finegrain matrix of $\mathrm{M}-\mathrm{Pt}$, melt flowage structures are observed (figure 2d), where melts of different colour (dark brown, light brown and dark green) occur adjacent to one another. Defocused raster beam analysis of these melt patches by electron probe micro analyser indicates that the dark melts have a composition rich in $\mathrm{K}_{2} \mathrm{O}, \mathrm{FeO} / \mathrm{Fe}_{2} \mathrm{O}_{3}$, $\mathrm{MgO}$ and $\mathrm{Al}_{2} \mathrm{O}_{3}$, whereas the lighter brown melts are less rich in Fe-oxides. It suggests that these melts are possibly produced by local melting of host rock minerals (e.g., biotite/K-feldspar) during crushing and melting of the host rock along the fault plane. Skeletal growth of iron oxides within the matrix, and spherulitic growth of biotite or iron oxide grains around relict quartz clasts also indicate crystallisation from a melt (e.g., Lofgren (1980)). C-Pt veins, on the other hand, comprise angular mineral and/or host rock fragments within a dark brown coloured matrix, and show a dominantly cataclastic texture under optical microscope (figure 2e). F-Ct comprises angular clasts of the country rock (granitic mylonite) along with relict clasts of quartz and feldspar (figure 2f). 

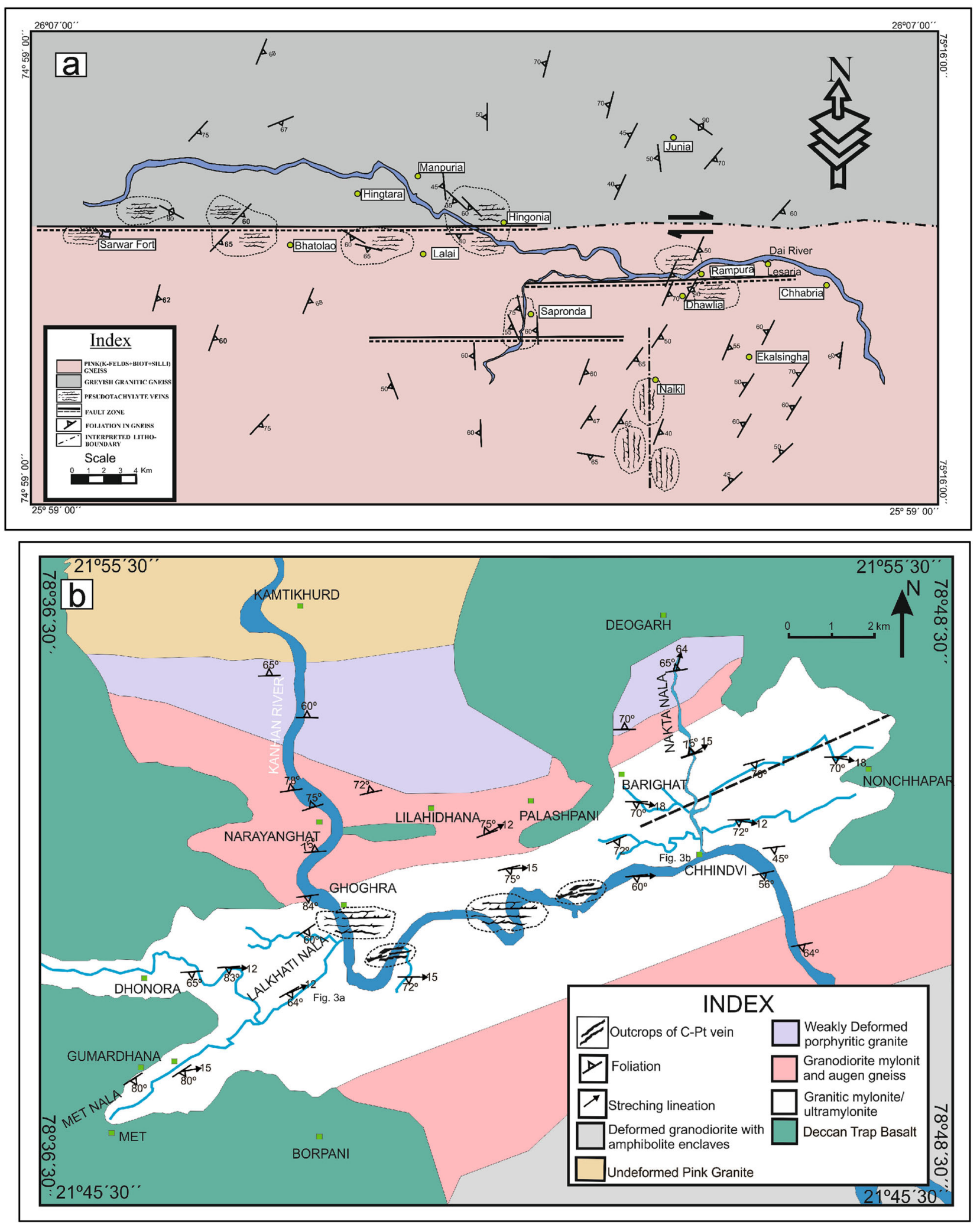

Figure 1. (a) Simplified geological map of Sarwar-Junia Fault Zone in Rajasthan, showing location of pseudotachylyte (MPt)-bearing exposures and (b) simplified Geological map of Gavilgarh-Tan Shear Zone, central India, showing location of pseudotachylyte (C-Pt) outcrops and the brittle fault zone (for F-Ct samples) (modified after Chattopadhyay and Khasdeo 2011). 

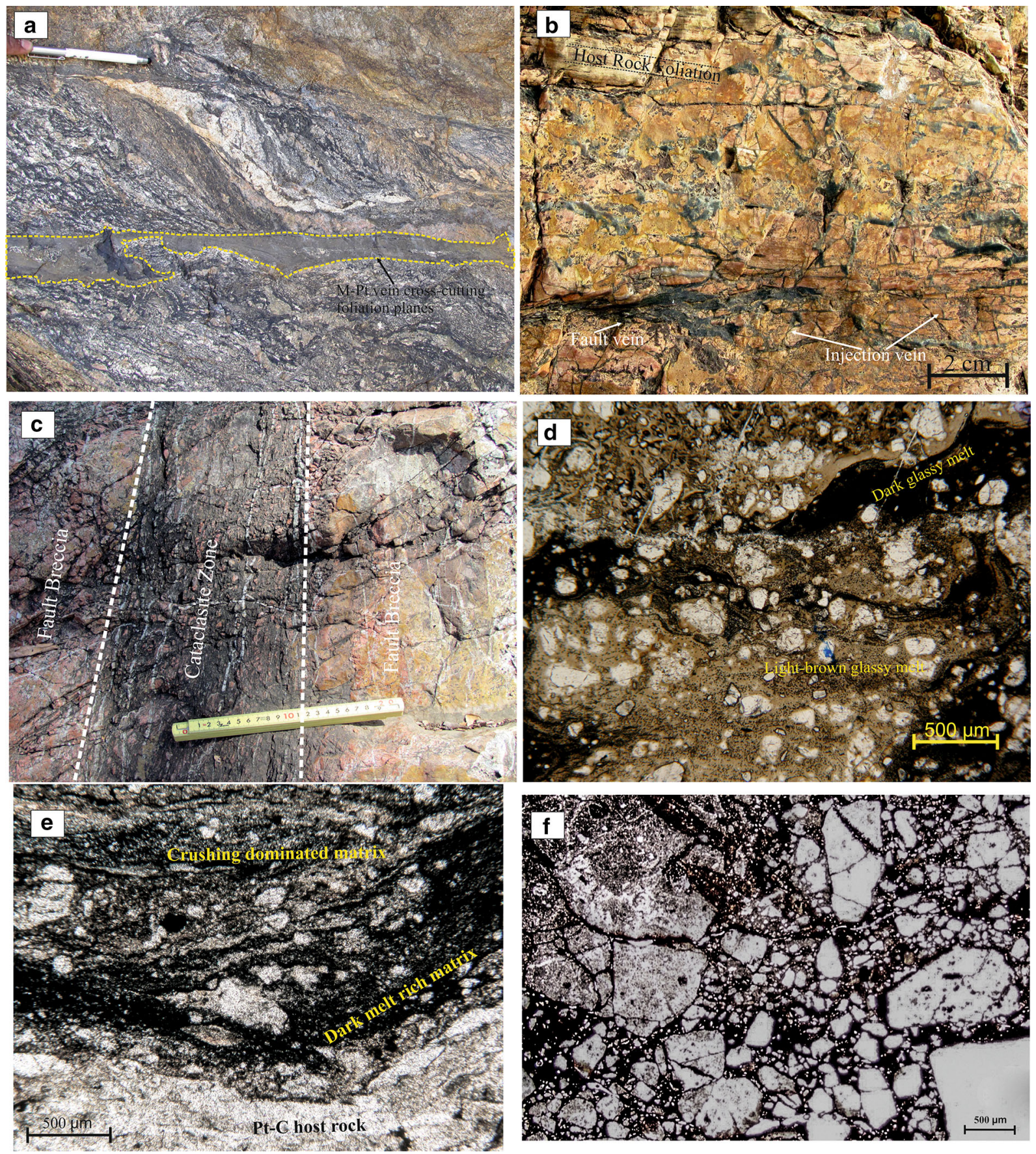

Figure 2. Mesoscopic and microscopic features of the fault rocks: (a) outcrop of M-Pt showing Pt-veins cutting across the gneissic foliation; (b) C-Pt fault veins and criss-cross pattern of injection veins within sheared aplitic granite; (c) outcrop of cataclastic rock within a fault breccia zone; (d) photomicrograph showing flow of melts of different colour and composition within M-Pt; (e) photomicropgraph of C-Pt showing intensely crushed host rocks with thin layers of dark coloured melt; and (f) angular clasts of host rock and minerals constitute the texture of F-Ct.

Fluid-induced alteration (e.g., saussuritisation) of feldspar grains are identified in a few thin sections, indicating fluid activity in parts of the brittle fault zone. F-Ct samples do not exhibit any evidence of melting under optical microscopy as well as under SEM. Neither do they have any vein system intruding the host rock in the fault outcrop, as discussed earlier. Therefore, F-Ct is considered as a purely crush-origin rock in our roundness analysis.

\section{Methodology of roundness analysis}

To quantify the shape of a clast, Wadell (1932) used 'Roundness' $\left(R_{\mathrm{d}}\right)$ as a parameter, which was 
a

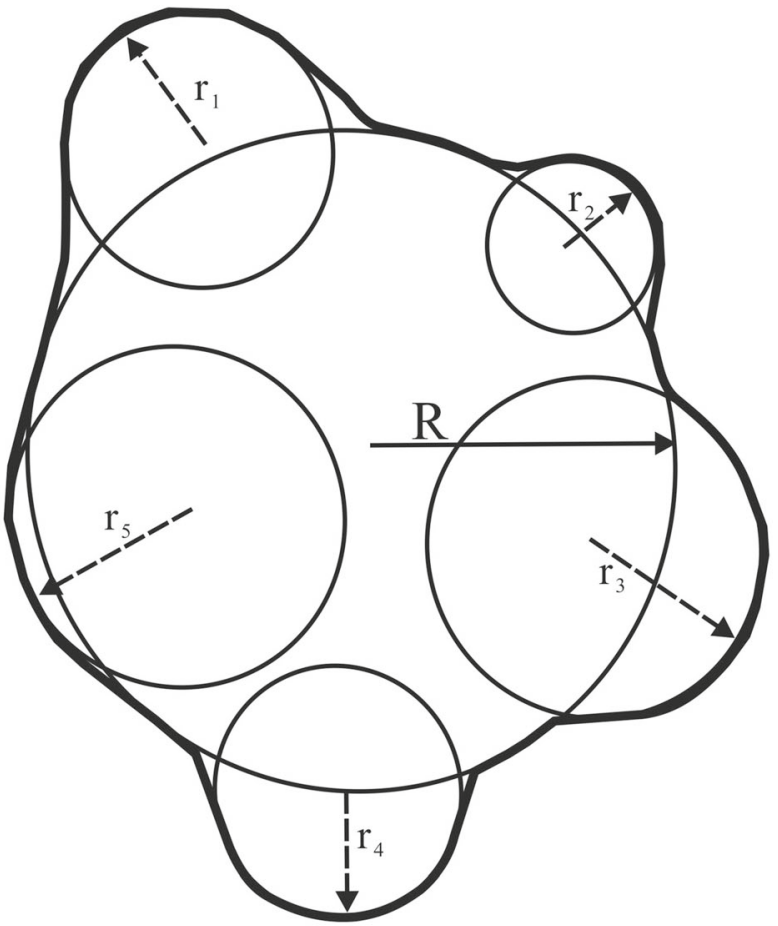

b

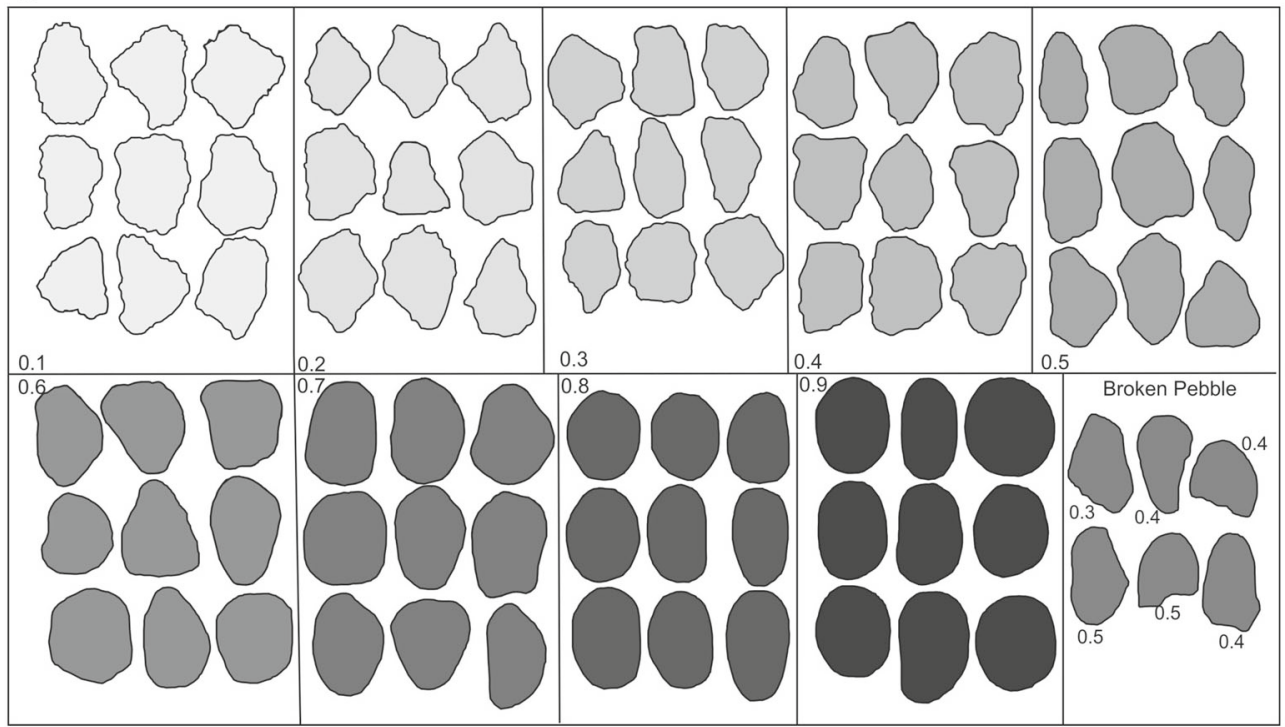

Figure 3. Roundness of a clast $\left(R_{\mathrm{d}}\right)$ as defined by Wadell (1932) and (b) Krumbein's (1941) image chart of roundness of fragments showing geometric shape of clasts with different $R_{\mathrm{d}}$ values for visual matching (modified after Lin 1999).

defined as: $R_{\mathrm{d}}=\Sigma\left(r_{i} / R\right) / n$, where $r_{i}$ is the radius of a circle fitted in the corner of the clast, $R$ is the radius of the largest circle inscribed in the plane of measurement and $n$ is the number of the corners of clasts in the given plane (figure $3 \mathrm{a}$ ). The roundness value found by this formula is always less than or equal to 1.0. The observed clasts and their roundness values can also be visually matched using Krumbein's Chart (figure 3b). Lin (1999) first attempted to quantify roundness of clasts in fault rocks following Wadell's method, as discussed in the earlier section. We also followed the same technique for roundness measurement in our fault-rock samples.

Roundness measurement was conducted on optical photomicrographs of the samples taken under plane polarised light. Only quartz and feldspar clasts were used as they are whitish in colour and could be easily distinguished from the dark-coloured matrix in a plane-polarised light photomicrograph. Circles were fitted into the images of clasts at high magnification. After 

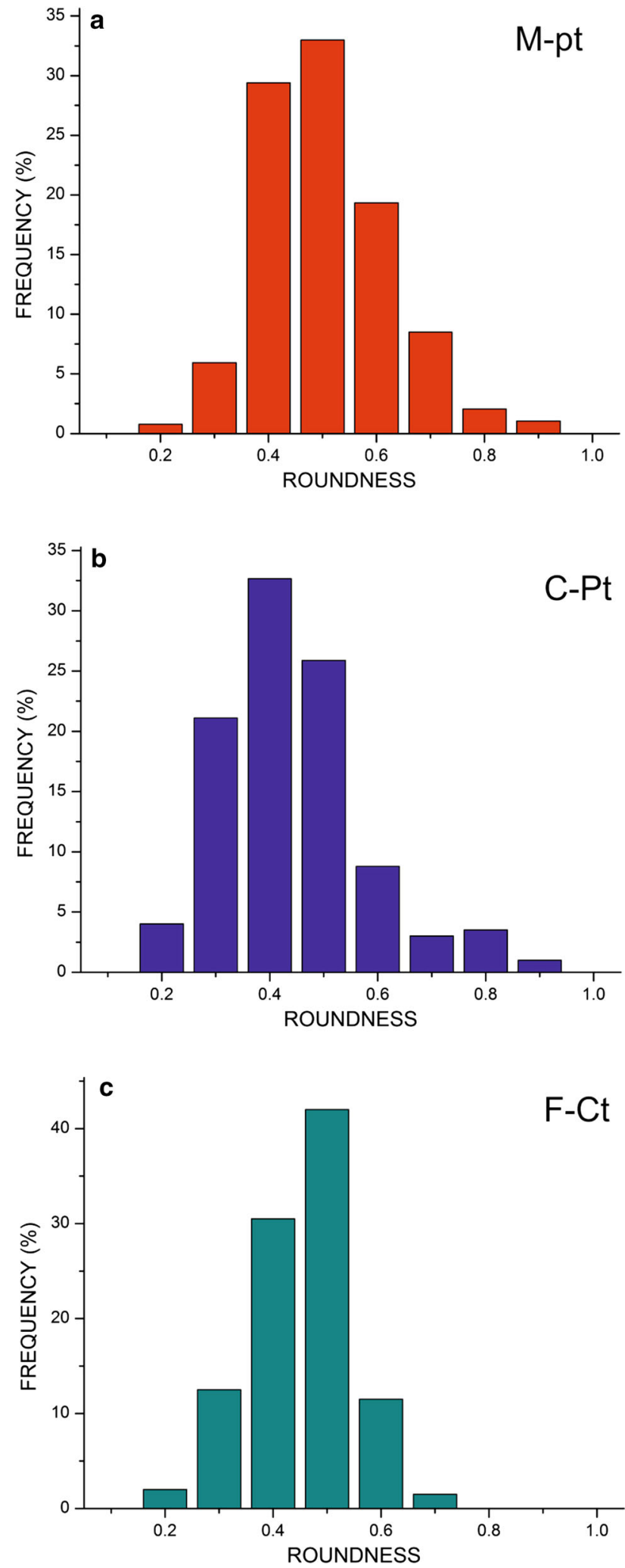

Figure 4. Histograms showing roundness of clasts against their frequency for $(\mathbf{a}) \mathrm{M}-\mathrm{Pt}(n=385)$, (b) C-Pt $(n=398)$, and (c) F-Ct $(n=306)$.

fitting one largest inscribed circle and the maximum possible number of circles at the corners that are sufficient to define the shape or irregularity of the clast (figure 3), the size (radii) of the circles were used for calculating the roundness according to Wadell's equation. It is difficult to fit and measure circles manually into the corners of the small clasts, and a large error is expected (Lin 1999). However, we did not have much problem there, as digital images can be magnified and circles can be fitted and measured easily, keeping the relative scales in consideration. Area of the same clasts (which were used for roundness calculation) was measured using digitised images of the clasts in ArcGIS $^{\mathrm{TM}}$. The area data were initially produced in pixel values in ArcGIS, which were then converted to real size using the pixel value of the scale of the concerned photomicrograph. For M-Pt and $\mathrm{C}-\mathrm{Pt}$, we measured the roundness of nearly 400 clasts each, whereas for F-Ct about 300 clasts were measured.

\section{Results of the clast roundness analysis}

The roundness data of the clasts are plotted against their percentage frequency (i.e., percentage of the total number of clasts measured in a sample) for M$\mathrm{Pt}, \mathrm{C}-\mathrm{Pt}$ and F-Ct (figure $4 \mathrm{a}-\mathrm{c}$ ). In all the graphs, clasts show a broad range of roundness values $(0.2$ 0.9 for M-Pt and C-Pt, and 0.2-0.7 for F-Ct). However, a very high percentage $(>80 \%)$ of clasts in M-Pt samples have $R_{\mathrm{d}} \approx 0.4-0.6$ and a peak frequency $(\sim 35 \%)$ with $R_{\mathrm{d}} \approx 0.5$ (figure $\left.4 \mathrm{a}\right)$. In C-Pt, $>80 \%$ clasts have roundness between 0.3 and 0.5 , with peak $(\sim 34 \%)$ at 0.4 (figure $4 \mathrm{~b})$. For F-Ct, nearly $80 \%$ clasts have roundness in the range of $0.4-0.5$ with peak $(>40 \%)$ at $R_{\mathrm{d}} \approx 0.5$ (figure $4 \mathrm{c}$ ).

When the area of the clasts were plotted against their roundness values for the different types of fault rocks (figure $5 \mathrm{a}-\mathrm{c}$ ), no well-defined pattern was found. The measured roundness values of smaller size clasts show larger scatter than that of the larger clasts, especially in M-Pt and C-Pt. This tendency is absent in the F-Ct sample (figure 5c).

\section{Discussion}

Lin (1999) documented that the fragments/clasts in pseudotachylyte are generally more rounded $\left(R_{\mathrm{d}}>0.4\right)$ than the clasts in fault gouge samples $\left(R_{\mathrm{d}}<0.4\right)$ measured by him. He explained that the higher roundness is a result of marginal decrepitation of the initially angular host rock/mineral fragments incorporated within the hot melt during pseudotachylyte formation. In melt-absent rocks, 

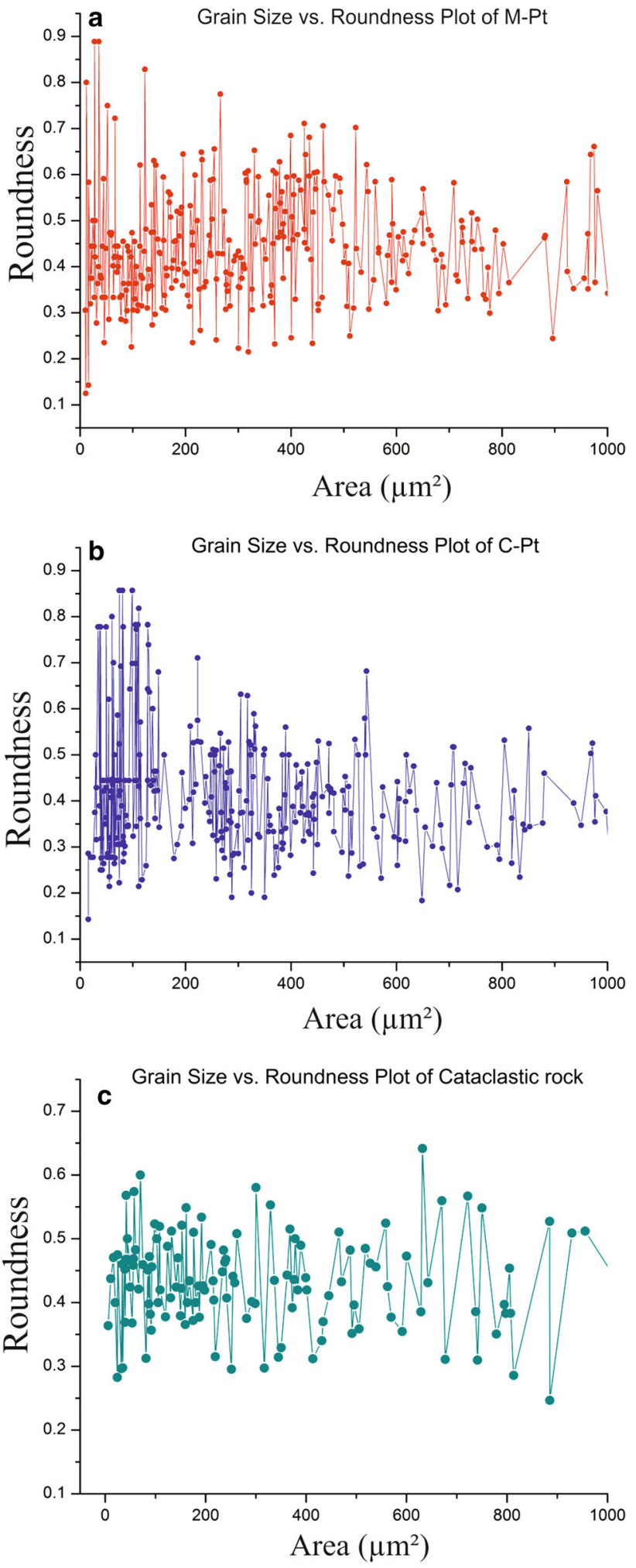

Figure 5. Graph of roundness $\left(R_{\mathrm{d}}\right)$ of clasts vs. their area for (a) M-Pt, (b) C-Pt, and (c) F-Ct. Note that there is no distinct pattern of variation of roundness with clast area. See text for details.

e.g., fault gouge or cataclasite, this rounding off is insignificant and therefore clasts show less roundness. On the basis of his study, Lin (1999) proposed that melt-origin fault rocks can be distinguished from crush-origin fault rocks using the roundness parameter $\left(R_{\mathrm{d}} \approx 0.4\right.$ being the boundary between the two types).

In the present study, we observed that a majority of the clasts in the melt-dominated pseudotachylyte (M-Pt) have a higher roundness $\left(R_{\mathrm{d}}>0.4\right)$ compared to the clasts in the C-Pt $\left(R_{\mathrm{d}}=0.3-0.4\right)$. However, the melt-absent cataclastic rock (F-Ct) shows majority of clasts with $R_{\mathrm{d}}>0.4$ (figure $4 \mathrm{a}-\mathrm{c}$ ). Therefore, distinction of melt-origin and crush-origin fault rocks solely on the basis of clast roundness value is unreliable for our samples. Another interesting observation from the present study is that size (area) of the clasts has no consistent correlation with roundness (figure 5). In the melt-origin pseudotachylyte, the smaller clasts usually undergo a greater degree of melting (e.g., Ray 1999). Therefore, more roundness is expected in smaller grains if melting only leads to enhanced roundness as argued by Lin (1999), and roundness vs. clast size graph should show a negative slope. In our M-Pt samples, some small size clasts show high roundness (as high as 0.9) (figure 5a). But they are very few in number and the mean roundness of small and large size grains are nearly identical (0.4-0.5). The negative slope expected from area vs. roundness graph is not observed in our M-Pt samples. This suggests that Lin's Lin (1999) idea, that clasts in melt-origin pseudotachylytes should have a higher roundness, may be partly true, but it is statistically not consistent enough to be used as a reliable discriminator between melt-origin and crush-origin fault rocks.

Angularity of clasts can also increase during melting. When a rock/mineral clast is entrapped within a melt, a thermal gradient is created between the clast margin (in contact with the hot melt) and the much cooler core (with ambient temperature of the host rock). This may lead to an anomalous thermal expansion of the clast leading to fracturing and disintegration of the clast, and creation of more angular fragments. In fact, this feature is observed in our M-Pt samples. A quartz clast within the dark coloured Pt-melt shows in-situ fracturing and intrusion of melt into the fractures (figure 6a). This fracturing cannot be due to crushing by frictional sliding because in that case the clast fragments would be separated from each other before being entrapped into the melt. This process produces increased number of small angular clasts within the melt, which do not get 

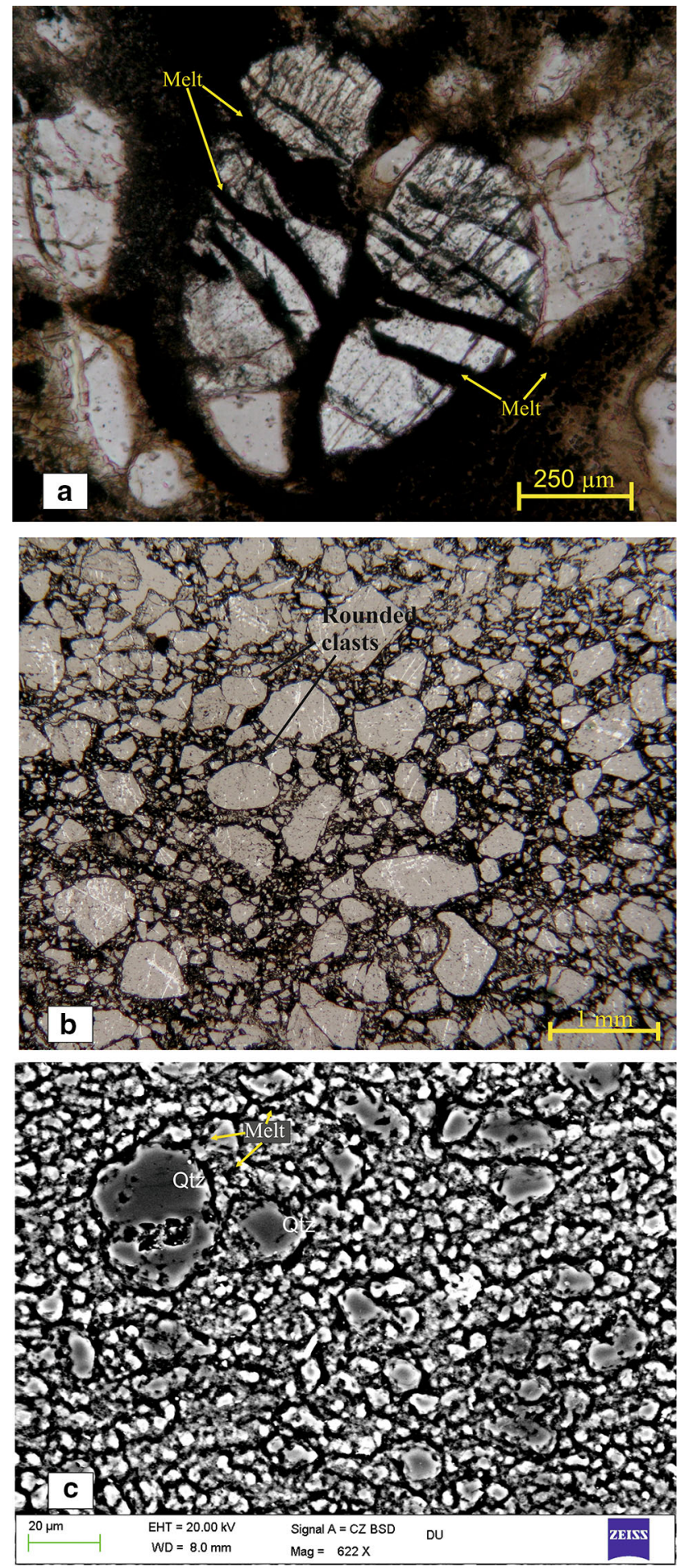

Figure 6. (a) Thermally induced fracturing and disintegration of quartz clast within melt in M-Pt; (b) a good number of rounded clasts occur within the F-Ct matrix; and (c) BSESEM image of cataclastic texture of C-Pt with thin dark coloured melt rims around the clast margins.

sufficient time to get rounded further, as the $\mathrm{Pt}$ melt cools down very rapidly (e.g., Di Toro and Pennacchioni 2004). The presence of a significant number of angular clasts (about $6 \%$ of the total number of clasts with $R_{\mathrm{d}}<0.4$ ) within the matrix of M-Pt (figure 5a) may be explained by this process. Similarly, in the purely crush-origin rock (i.e., F-Ct), rock fragments (clasts) can be rounded off by abrasion and attrition during rolling (Chester et al. 1993). Our F-Ct sample shows a significant number of round-shaped clasts under the microscope (figure 6b), which can possibly explain the high roundness values observed in the analyses (figure 5c). Under an SEM, the C-Pt clearly shows a cataclastic texture and the clasts are found to be surrounded by a very thin rim of very dark coloured melt of a mixed biotite-K-feldspar composition as determined by energy-dispersive X-ray spectroscopy (figure 6c). The microstructural features of C-Pt indicate a crushing (cataclasis) dominated origin with very limited melting along the clast margins. Therefore, not many angular clasts could get rounded off by melt-clast interaction, as in M-Pt. Peak roundness value $\left(R_{\mathrm{d}} \approx 0.3-0.5\right)$ of $\mathrm{C}-\mathrm{Pt}$ is therefore less than M-Pt and F-Ct. However, it may be noted that the roundness values of F-Ct clasts are always below 0.7 , whereas a much higher roundness is observed in $\mathrm{M}-\mathrm{Pt}$ and $\mathrm{C}-\mathrm{Pt}$ $\left(R_{\mathrm{d}} \approx 0.8-0.9\right)$ which involve at least some amount of melting. This suggests that melting may enhance the roundness of an individual clast, but statistical analysis of roundness of clasts is a not a reliable discriminator between melt-origin and crush-origin fault rocks.

\section{Conclusion}

The following major conclusions come out of our analysis of roundness of clasts in different types of melt-origin and crush-origin fault rocks:

(1) Roundness of survivor quartz-feldspar clasts is, in general, higher in melt-origin fault rocks (i.e., pseudotachylytes) due to rounding off of the angular clasts during melt-clast interaction. However, a definite roundness value $\left(R_{\mathrm{d}} \approx 0.4\right.$, as suggested by Lin 1999) cannot be ascertained that consistently distinguishes melt-origin rocks from crush-origin rocks.

(2) Rolling clasts in crush-origin rocks (i.e., cataclasites) can also have significant roundness $\left(R_{\mathrm{d}} \approx 0.5\right)$, but a very high roundness $\left(R_{\mathrm{d}}>\right.$ 0.7 ) of clast is not achieved by physical abrasion in a brittle fault zone. 
(3) Thermal fracturing of large quartz/feldspar clasts in contact with the hot melt in pseudotachylyte may produce new angular clasts and therefore can increase the statistical proportion of angular clasts in melt-origin fault rocks. This also explains why smaller clasts in melt-origin pseudotachylytes (M-Pt), which are expected to have greater roundness due to enhanced melt-clast interaction, are not actually showing any such definite trend.

\section{Acknowledgements}

This work was supported by a UGC-MRP Grant (F. No. 42-66/2013 (SR)) and partially by a Delhi University Faculty R\&D Grant (No. RC/2014/ 6820) awarded to AC. AS was supported through the aforesaid UGC project fellowship. Microscopy and software facility were provided by the Department of Geology, University of Delhi.

\section{References}

Behera B M, Thirukumaran V, Soni A, Mishra P K and Biswal T K 2017 Size distribution and roundness of clasts within pseudotachylytes of the Gangavalli Shear Zone, Salem, Tamil Nadu: An insight into its origin and tectonic significance; J. Earth Syst. Sci. 126(4) 46.

Chattopadhyay A and Khasdeo L 2011 Structural evolution of Gavilgarh-Tan Shear Zone, central India: A possible case of partitioned transpression during Mesoproterozoic oblique collision within central Indian tectonic zone; Precamb. Res. 186(1) 70-88.

Chattopadhyay A, Khasdeo L, Holdsworth R E and Smith S A F 2008 Fault reactivation and pseudotachylite generation in the semi-brittle and brittle regimes: Examples from the Gavilgarh-Tan Shear Zone, central India; Geol. Mag. 145(6) 766-777.

Chester F M, Evans J P and Biegel R 1993 Internal structure and weakening mechanisms of the San Andreas Fault; J. Geophys. Res. 100 13,007-13,020.

Cowan D S 1999 Do faults preserve a record of seismic slip? A field geologist's opinion; J. Struct. Geol. 21(8) 995-1001.

Di Toro G and Pennacchioni G 2004 Superheated frictioninduced melts in zoned pseudotachylytes within the Adamello tonalites (Italian Southern Alps); J. Struct. Geol. 26 1783-1801.

Gupta S N, Arora Y K, Mathur R K, Iqbaluddin B P, Sahai, T N, Sharma S B and Murthy M V N 1980 Lithostratigraphic map of Aravalli region, southern Rajasthan and northeastern Gujarat; Geol. Surv. India, Calcutta.

Heron A M 1953 The geology of central Rajputana; Gov. India Press 79(1) 1-389.

Kirkpatrick J D, Dobson K J, Mark D F, Shipton Z K, Brodsky E E and Stuart F M 2012 The depth of pseudotachylyte formation from detailed thermochronology and constraints on coseismic stress drop variability; J. Geophys. Res. Solid Earth 117B6.

Krumbein WC 1941 Measurement and geologic significance of shape and roundness of sedimentary particles; J. Sedim. Petrol. 11 64-72.

Legros F, Cantagrel J M and Devouard B 2000 Pseudotachylyte (frictionite) at the base of the Arequipa volcanic landslide deposit (Peru): Implications for emplacement mechanisms; J. Geol. 108(5) 601-611.

Lin A 1994 Glassy pseudotachylyte veins from the Fuyun fault zone, northwest China; J. Struct. Geol. 16(1) 7183.

Lin A 1996 Injection veins of crushing-originated pseudotachylyte and fault gouge formed during seismic faulting; Eng. Geol. 43(2) 213-224.

Lin A 1999 Roundness of clasts in pseudotachylytes and cataclastic rocks as an indicator of frictional melting; J. Struct. Geol. 21(5) 473-478.

Lin A 2008 Seismic slip in the lower crust inferred from granulite-related pseudotachylyte in the Woodroffe Thrust, central Australia; Pure Appl. Geophys. 165(2) 215-233.

Lin A and Shimamoto T 1998 Selective melting processes as inferred from experimentally generated pseudotachylytes; J. Asian Earth Sci. 16(5) 533-545.

Lofgren G 1980 Experimental studies on the dynamic crystallization of silica melts; In: Physical magmatic process (ed.) Hargraves R B, Princeton University Press, Princeton, New Jersey, pp. 487-551.

Maddock R H 1983 Melt origin of fault-generated pseudotachylytes demonstrated by textures; Geology $\mathbf{1 1}(\mathbf{2})$ 105-108.

Magloughlin J F 1992 Microstructural and chemical changes associated with cataclasis and frictional melting at shallow crustal levels: The cataclasite-pseudotachylyte connection; Tectonophys. 204(3-4) 243-260.

Magloughlin J F and Spray J G 1992 Frictional melting processes and products in geological materials: Introduction and discussion; Tectonophys. 204(3-4) $197-$ 204.

McKenzie D and Brune J N 1972 Melting on fault planes during large earthquakes; Geophys. J. Roy. Astron. Soc. 29(1) 65-78.

Ray S K 1999 Transformation of cataclastically deformed rocks to pseudotachylyte by pervasion of frictional melt: Inferences from clast-size analysis; Tectonophys. 301(3) 283-304.

Ray S K 2004 Melt-clast interaction and Power-law size distribution of clasts in pseudotachylytes; J. Struct. Geol. 26(10) 1831-1843.

Reimold W U and Gibson R L 2005 'Pseudotachylite' in large impact structures; In: Impact tectonics (eds) Koeberl $\mathrm{C}$ and Henkel H, Impact Studies Series, No. 6, SpringerVerlag, pp. 1-53.

Sammis C, King G and Biegel R 1987 The kinematics of gouge deformation; Pure Appl. Geophys. 125(5) 777812.

Shand S J 1916 The pseudotachylyte of Parijs (Orange free State), and its relation to 'Trap-Shotten Gneiss' and 'Flinty Crush-rock'; Quart. J. Geol. Soc. London 72(1-4) 198-221. 
Shimamoto T and Nagahama H 1992 An argument against the crush origin of pseudotachylytes based on the analysis of clast-size distribution; J. Struct. Geol. 14(8-9) 9991006.

Sibson R H 1975 Generation of pseudotachylyte by ancient seismic faulting; Geophys. J. Roy. Astron. Soc. 43(3) 775794.

Sibson R H 1977 Fault rocks and fault mechanisms; J. Geol. Soc. London 133(3) 191-213.

Spray J G 1995 Pseudotachylyte controversy: Fact or friction? Geology 23(12) 1119-1122.

Corresponding editor: SAIBAL GUPTA
Tsutsumi A 1999 Size distribution of clasts in experimentally produced pseudotachylytes; J. Struct. Geol. 21(3) 305312.

Wadell H A 1932 Volume, shape, and roundness of rock particles; J. Geol. 40 443-451.

Wenk H R 1978 Are pseudotachylites products of fracture or fusion? Geology 6(8) 507-511.

Wenk H R and Weiss L E 1982 Al-rich calcic pyroxene in pseudotachylite: An indicator of high pressure and high temperature? Tectonophys. 84(2-4) 329-341. 